\title{
Estimation of excess all-cause mortality due to COVID-19 in
}

4 Chaiwat Wilasang ${ }^{1}$, Thanchanok Lincharoen${ }^{1}$, Charin Modchang ${ }^{1,2,3}$, Sudarat Chadsuthi ${ }^{4}$

$5 \quad{ }^{1}$ Biophysics Group, Department of Physics, Faculty of Science, Mahidol University, Bangkok

6 10400, Thailand.

$7 \quad{ }^{2}$ Centre of Excellence in Mathematics, CHE, Ministry of Education, Bangkok 10400, Thailand.

$8{ }^{3}$ Thailand Center of Excellence in Physics, Commission on Higher Education, Bangkok 10400, 9 Thailand.

$10{ }^{4}$ Department of Physics, Research Center for Academic Excellence in Applied Physics, Faculty of 11 Science, Naresuan University, Phitsanulok 65000, Thailand.

12

$13 *$ Corresponding author: Sudarat Chadsuthi

14 Department of Physics, Faculty of Science, Naresuan University, Phitsanulok 65000, Thailand

15 E-mail: sudaratc@nu.ac.th,schadsuthi@gmail.com 
medRxiv preprint doi: https://doi.org/10.1101/2022.01.07.22268886; this version posted January 7, 2022. The copyright holder for this preprint (which was not certified by peer review) is the author/funder, who has granted medRxiv a license to display the preprint in perpetuity.

It is made available under a CC-BY 4.0 International license.

\section{Abstract}

17 Background: Thailand has recently experienced the most prominent COVID-19 outbreak, 18 resulting in a new record for COVID-19 cases and deaths. To assess the influence of the COVID1919 outbreak on mortality, we aimed to estimate excess mortality in Thailand.

20 Methods: We estimated the baseline number of deaths in the absence of COVID-19 using 21 generalized linear mixed models (GLMMs). The models were adjusted for seasonality and 22 demographics. We evaluated the excess mortality from April to October 2021 in Thailand.

23 Results: We found that the estimated cumulative excess death from April to October 2021 was $24 \quad 14.3 \%(95 \% \mathrm{CI}: 8.6 \%-18.8 \%)$ higher than the baseline. The results also showed that the excess 25 deaths in males were higher than in females by approximately $26.3 \%$. The excess deaths directly 26 caused by the COVID-19 infections accounted for approximately $75.0 \%$ of the all-cause excess

27 deaths. Furthermore, the cumulative COVID-19 cases were found to be correlated with the 28 cumulative excess deaths with a correlation coefficient of 0.9912 (95\% CI, 0.9392-0.9987).

29 Conclusions: The recent COVID-19 outbreak in Thailand significantly impacts mortality and 30 affects people for specific ages and sex. During the outbreak in 2021, there was a significant rise 31 in excess fatalities, especially in the older age groups. The increase in mortality was higher in men 32 than in women.

33 Keywords: Excess mortality, COVID-19, Thailand 
medRxiv preprint doi: https://doi.org/10.1101/2022.01.07.22268886; this version posted January 7, 2022. The copyright holder for this preprint (which was not certified by peer review) is the author/funder, who has granted medRxiv a license to display the preprint in perpetuity.

It is made available under a CC-BY 4.0 International license.

\section{Background}

Thailand has recently experienced the most prominent coronavirus disease 2019 (COVID19) outbreak in $2021[1,2]$. To mitigate the disease transmission, the Thai government implemented social distancing and stringent lockdown measures throughout the country and imposed international travel restrictions and nighttime curfews[3]. Even though the interventions have proven to be effective in slowing down the spread of the disease, during the peak of the epidemic wave, hospitals in Thailand were running out of beds to accommodate COVID-19 patients and patients of other diseases[4-6]. Although the Thai government had set up the field hospitals[7] for treating COVID-19 patients, the disease's toll on mortality was still high[8]. According to a recent report by the Department of Disease Control, Ministry of Public Health, Thailand $^{3}$, there were 19,111 officially reported COVID-19 deaths since the beginning to October 31, 2021. This number of deaths reflects the significant impact of the COVID-19 outbreaks on mortality in Thailand.

To assess the impact of the outbreak on mortality, the approach for estimating excess mortality was utilized to quantify the increased deaths compared with the expected mortality. Excess mortality estimation has previously been used to investigate the effects of pollution[9], climate change[10], and epidemics (e.g., influenza[11, 12], chikungunya[13], and HIV[14]). Moreover, previous studies have also applied this approach to COVID-19, focusing on estimating the mortality burden of the COVID-19 outbreak using statistical models. In general, statistical models usually incorporate risk factors related to death (e.g., sex, age group, time, seasonality, and demographic change) as indicator functions for excess mortality estimation. For instance, J. M. Aburto et al.,[15] estimated the number of age- and sex-specific excess deaths adjusted for seasonality using generalized additive models (GAM).

In this study, we aimed to estimate excess mortality in Thailand from April to October 2021 to assess the impact of the COVID-19 outbreaks on mortality. We estimated the baseline number of deaths in a typical year without COVID-19 using a generalized linear mixed model (GLMM). Our model incorporated several factors such as sex, age group, time, seasonality, and demographics. We then estimated the all-cause mortality from April to October 2021 compared to baseline. 
medRxiv preprint doi: https://doi.org/10.1101/2022.01.07.22268886; this version posted January 7, 2022. The copyright holder for this preprint (which was not certified by peer review) is the author/funder, who has granted medRxiv a license to display the preprint in perpetuity.

It is made available under a CC-BY 4.0 International license.

\section{Materials and methods}

66

67

68

69

70

71

72

73

74

75

76

77

78

79

80

81

82

83

84

85

86

\section{Estimating the excess mortality} of age).

We collected the monthly all-cause mortality data in Thailand from Official Statistics Registration Systems in the human mortality database[16]. The database compiles mortality statistics from Thailand's Bureau of Registration Administration. The information was presented in the form of tables with age and gender categories. The mortality data from 2015 to 2019 was utilized to estimate the baseline mortality in the absence of COVID-19 in 2020-2021. The number of deaths was categorized into six age groups $(0-14,15-18,19-24,25-34,35-60$, and over 60 years

The number of daily COVID-19 cases and deaths in Thailand were retrieved from the Center for Systems Science and Engineering (CSSE) at Johns Hopkins University[17]. Daily COVID-19 mortality data were summarized into monthly data for consistency with the monthly all-cause mortality. According to the COVID-19 mortality data, the number of confirmed deaths started to increase rapidly in early April 2021 (see Fig S1 in the supplementary information). We, therefore, focused our attention on estimating the excess deaths from April to October 2021, a period in which the cumulative number of COVID-19 deaths exceeds 100.

We also obtained yearly population estimates from the Population Pyramids of the World from 2015 to 2021[18]. The single-year population counts were aggregated to match the gender and age group of the mortality data. We employed the standard interpolation approach[15] to estimate the monthly population by gender and age group. The monthly population counts were used as an offset in the modelling strategy to calculate the baseline mortality in Thailand.

In order to estimate the excess mortality, we started our analysis by investigating the distribution of the observed sex-specific death counts from 2015 to 2019 . We then used mortality data from January 2015 to December 2019 to estimate the baseline mortality in the absence of 
medRxiv preprint doi: https://doi.org/10.1101/2022.01.07.22268886; this version posted January 7, 2022. The copyright holder for this preprint (which was not certified by peer review) is the author/funder, who has granted medRxiv a license to display the preprint in perpetuity.

It is made available under a CC-BY 4.0 International license .

91

92

93

94

95

96

97

98

99

100

101

102

103

104

105

106

107

108

109

110

111

112

113

114

115

COVID-19. The mortality data were fitted by generalized linear mixed models (GLMMs) with a negative binomial function. The models included linear mortality trends by gender, age, and seasonality. The structure of the models was as follows:

$Y_{t} \sim \beta_{1} *$ FirstMonthofYear $*$ sex $_{t} *$ agegroup $_{t}$

$$
+\beta_{2} * \text { LastMonthofYear } * \operatorname{sex}_{t} * \text { agegroup }_{t}
$$$$
+\beta_{3} * \operatorname{time}_{t} * \operatorname{sex}_{t} * \operatorname{agegroup}_{t}
$$$$
+\beta_{4} * \sin \left(\frac{2 \pi *(\text { month } / 30)}{365.25}\right) * \text { sex }_{t} * \text { agegroup }_{t}
$$$$
+\beta_{5} * \cos \left(\frac{2 \pi *(\text { month/30) }}{365.25}\right) * \operatorname{sex}_{t} * \text { agegroup }_{t}
$$

$+\beta_{6} *$ offset $\left(\log \left(\right.\right.$ exposure $\left.\left._{t}\right)\right)$

$+\mu(1 \mid$ year $)$

where $Y_{t}$ is the expected number of deaths at month $t$. sex $x_{t}$ and $\operatorname{agegroup}_{t}$ represent the gender and age group at month $t$. FirstMonthofYear and LastMonthofYear are indicator variables

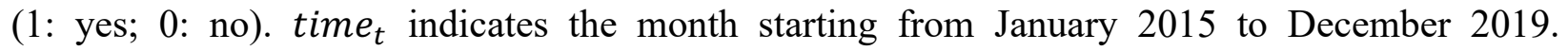
Furthermore, the featuring trigonometric terms represent the seasonal effect, and all the terms are fully interacted with gender and age group. month indicates the month of the year. This model also captures a yearly trend of changing population structure. The monthly average population by age group and gender at month $t$ ( exposure $_{t}$ ) was used as an offset in the modelling. Here, year is a random effect in the model. The baseline was then created by averaging the death counts observed in each month starting from January 2015 to December 2019.

We then projected the baseline mortality forward until October 2021. The excess mortality in each month was defined as the number of reported deaths minus the baseline prediction. We subsequently summed the excess mortality estimates across all months, starting from April 1, 2021 , to October 31, 2021, yielding the cumulative estimate of the excess mortality in Thailand.

We also compare our model with other GLMMs (for full details, see the supplementary information). All the analyses were implemented in $\mathrm{R}$ statistical software version 3.6.3. To 
medRxiv preprint doi: https://doi.org/10.1101/2022.01.07.22268886; this version posted January 7, 2022. The copyright holder for this preprint (which was not certified by peer review) is the author/funder, who has granted medRxiv a license to display the preprint in perpetuity.

It is made available under a CC-BY 4.0 International license .

116

117

118

119

120

121

122

123

124

125

126

127

128

129

130

131

132

133

134

135

136

137

138

139

140

141

142

calculate the $95 \%$ confidence interval (CI), we sampled death counts from a negative binomial distribution, following an approach developed by J. M. Aburto et al.,[15].

\section{Results}

Thailand has been plagued by competition between Alpha and Delta variants since April 2021[1, 2], resulting in Thailand's most ever severe epidemic wave. The number of COVID-19 deaths has increased across the country (Fig. S1). Until August 2021, daily deaths reached their peak with an average of 235 deaths per day[19]. Following that, the death toll continued to decrease, with an average of 99 deaths per day in October[20]. During April to late August, there were more than 10,000 officially COVID-19 confirmed deaths in Thailand.

This study estimated excess mortality in Thailand during the COVID-19 outbreak using GLMM. To do so, we first evaluated the ability of different models to retrospectively explain the mortality data from 2015 to 2019. The baseline mortality estimated using different models described in the method section is shown in Fig. S2-S5 in the supplement information. By comparing these modeling results, we found that the GLMM with age and sex specific effects for special months (i.e., the first and last months of a year) yields the best result based on the Akaike information criterion (AIC) (Table S1. in supplement information).

\section{Baseline mortality during 2015 - 2021}

Figures 1 and 2 show the observed and baseline mortality stratified by age group in 20152021 for men and women, respectively. The observed number of deaths is indicated by the points, and the expected number of deaths is illustrated by the solid line along with their $95 \%$ CI. Overall, the trends of monthly deaths generated from the model agree with the reported data. We also predicted the baseline mortality in 2020-2021 based on the 2015-2019 mortality data. We found that the predicted baseline in 2020-2021 during COVID-19 outbreak was higher than the reported mortality data in the younger age group (0-14) of men, whereas the predicted baseline in other age groups agreed with the mortality data. 
medRxiv preprint doi: https://doi.org/10.1101/2022.01.07.22268886; this version posted January 7, 2022. The copyright holder for this preprint (which was not certified by peer review) is the author/funder, who has granted medRxiv a license to display the preprint in perpetuity.
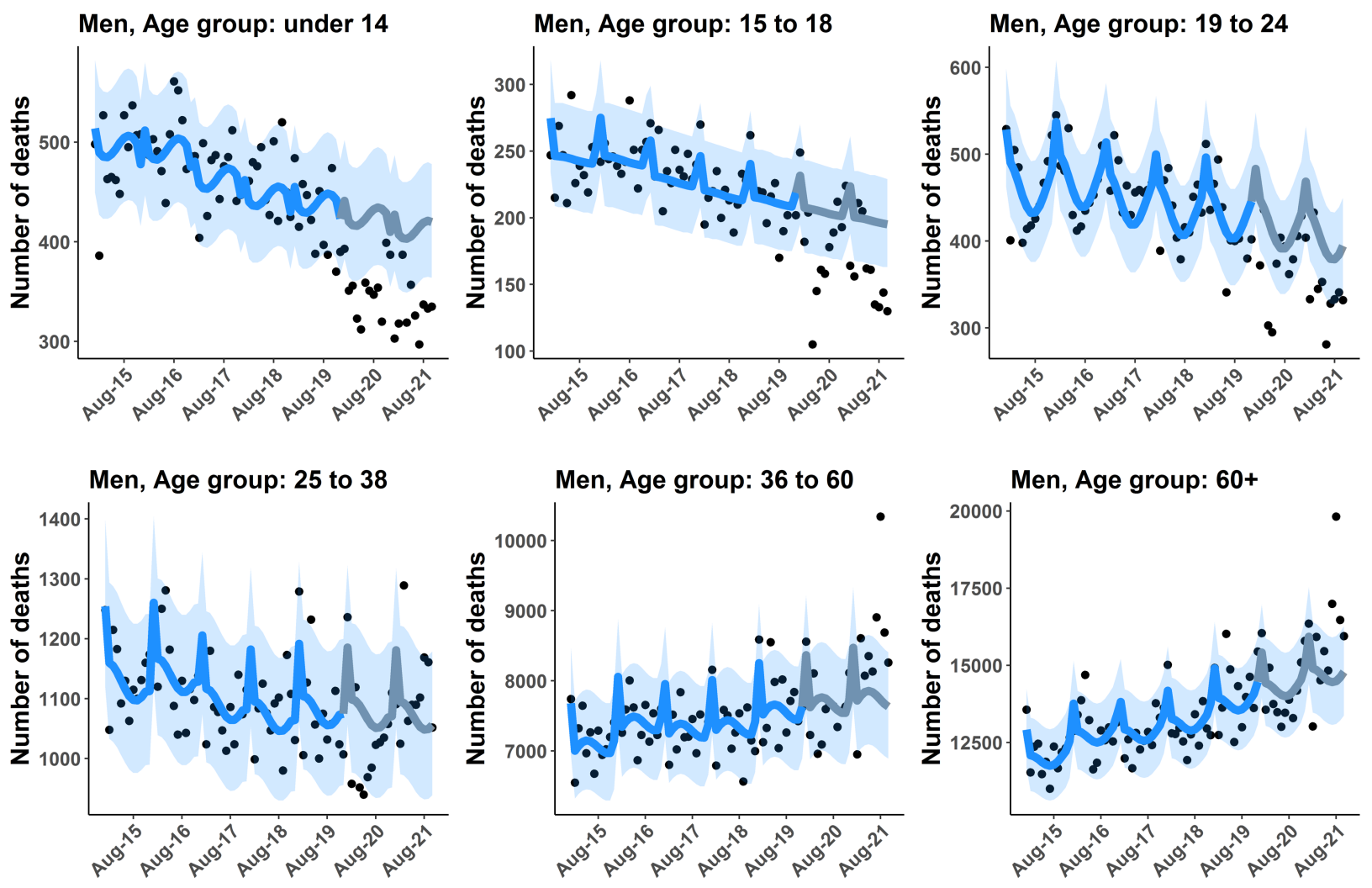

Figure 1. Men baseline mortality. Lines illustrate the baseline mortality by six age groups (0-14,

$14515-18,19-24,25-34,35-60$, and over 60 years of age). Grey lines show the predicted baseline 146 starting from January 2020 to October 2021. Points show the observed mortality data. Shaded 147 areas indicate $95 \% \mathrm{CI}$. 
medRxiv preprint doi: https://doi.org/10.1101/2022.01.07.22268886; this version posted January 7, 2022. The copyright holder for this preprint (which was not certified by peer review) is the author/funder, who has granted medRxiv a license to display the preprint in perpetuity.

It is made available under a CC-BY 4.0 International license .
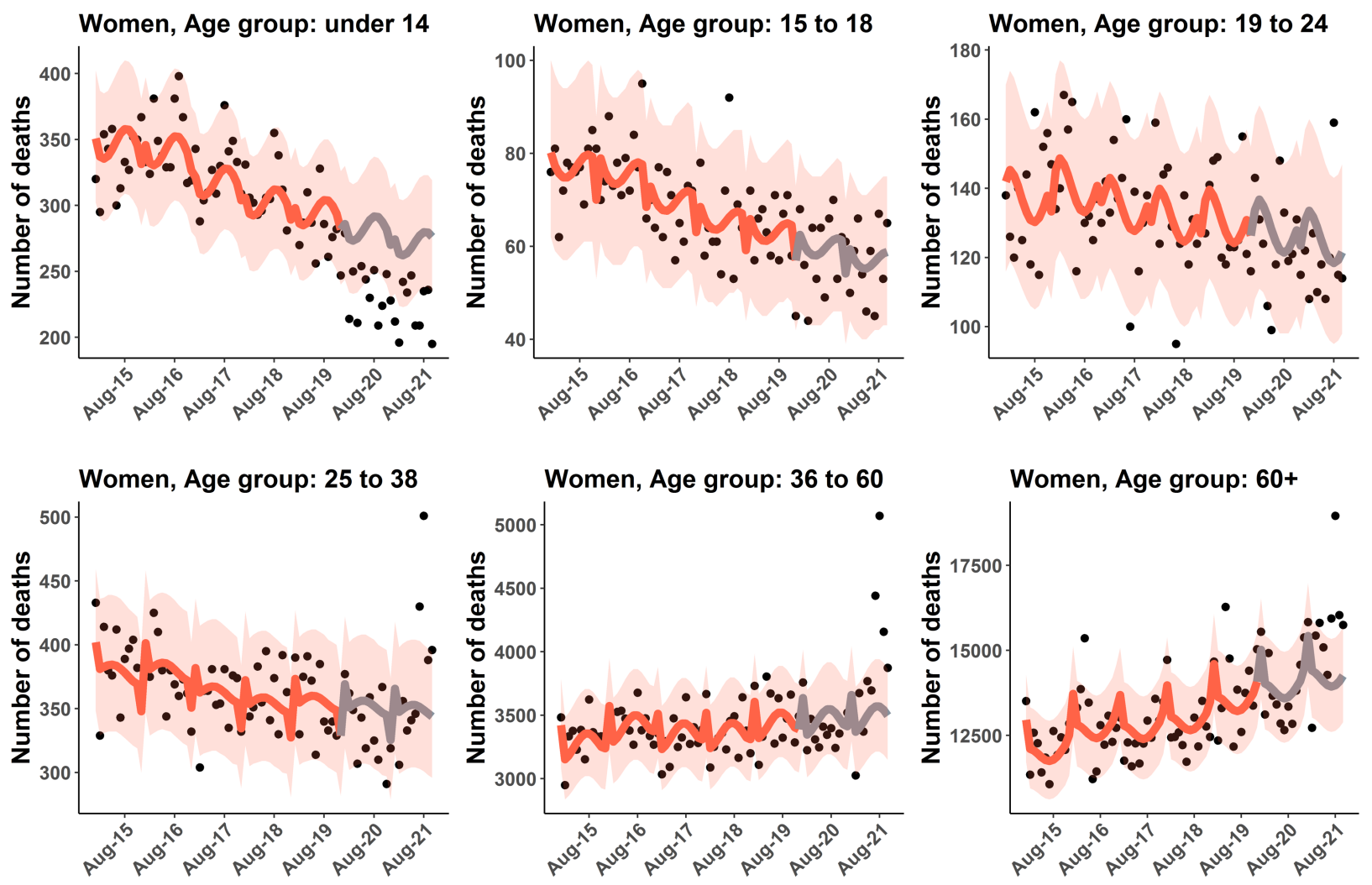

148

149

150

151

152

153

154

155

156

157

158

159

160

161

162

Figure 2. Women baseline mortality. Lines illustrate the baseline mortality by six age groups (0$14,15-18,19-24,25-34,35-60$, and over 60 years of age). Grey lines show the predicted baseline starting from January 2020 to October 2021. Points show the observed mortality data. Shaded areas indicate $95 \% \mathrm{CI}$.

\section{Cumulative excess mortality}

The estimated cumulative excess deaths from April to October 2021 for men and women is shown in Fig. 3. The expected number of all-cause excess deaths up to October 31, 2021 was 25,486 (95\% CI: 13,913-36,862). We found that the cumulative death counts had risen by $14.3 \%$ (95\% CI: 8.6\%-18.8\%) above the baseline. The results showed that male excess deaths accounted for $55.8 \%(14,223)$ of total excess deaths, while female excess deaths accounted for $44.2 \%$ $(11,263)$. These excess deaths included deaths caused by COVID-19 and other causes. Up to October 31, 2021, there were 19,111 officially reported COVID-19 deaths. After classifying the deaths caused by COVID-19, we found that the deaths attributed to COVID-19 accounted for 
medRxiv preprint doi: https://doi.org/10.1101/2022.01.07.22268886; this version posted January 7, 2022. The copyright holder for this preprint (which was not certified by peer review) is the author/funder, who has granted medRxiv a license to display the preprint in perpetuity.

It is made available under a CC-BY 4.0 International license .

163 164

$75.0 \%$ of the excess deaths throughout the study period, with the remaining $25.0 \%(6,375)$ being indirectly attributed to COVID-19.
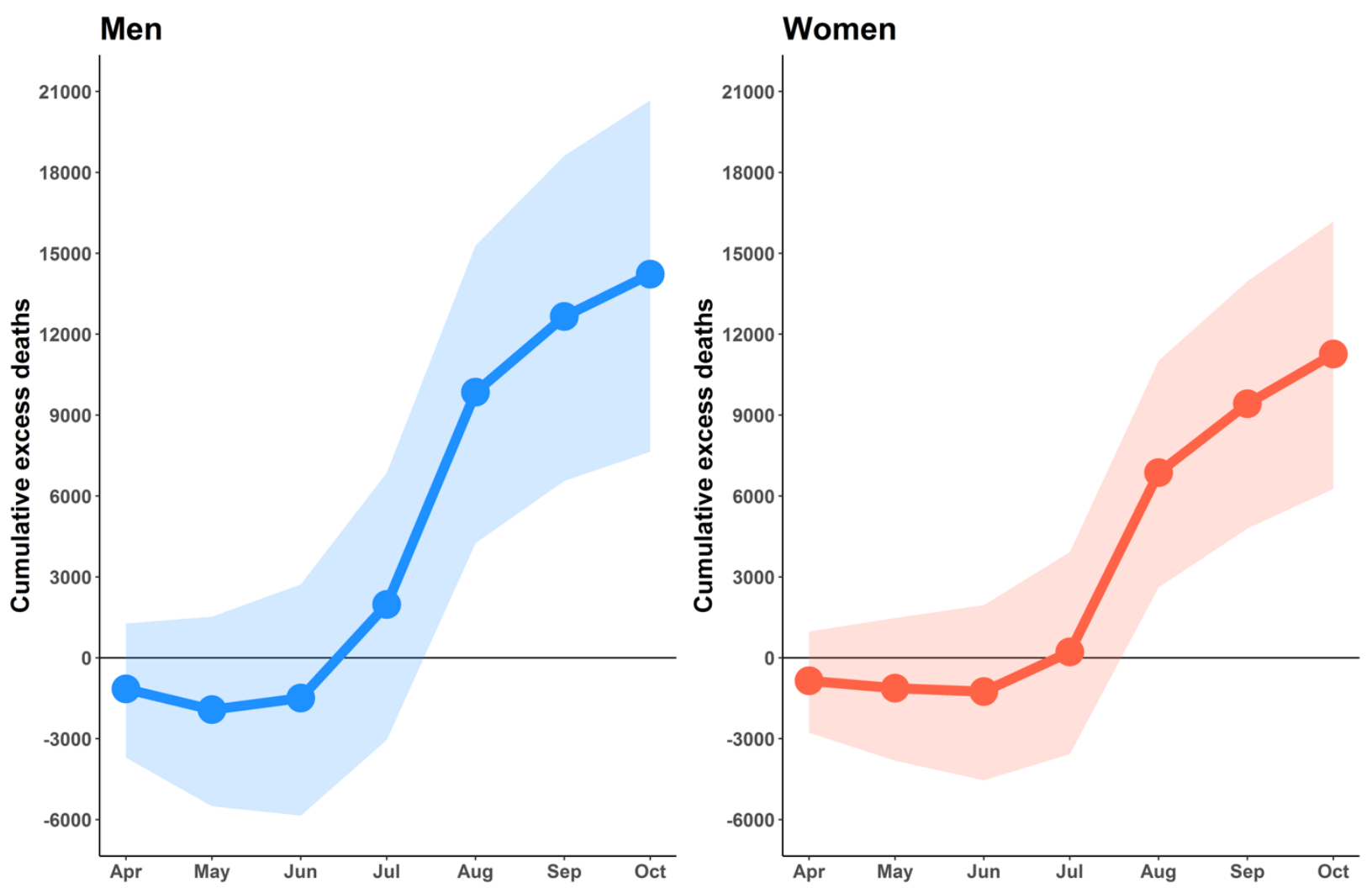

165

166

167 168

169

170

171

172

173

174

175

176

Figure 3. Cumulative excess deaths by gender starting from April to October 2021. Lines

illustrate the cumulative excess deaths by gender. Shaded areas show 95\% prediction intervals.

According to the time series of all-cause excess deaths, the number of excess deaths began to rise above the baseline in July 2021 (Fig. 3), which was the first month that the daily number of COVID-19 deaths exceeds a hundred. For both men and women, excess deaths were obviously observed in age groups older than 25 years, whereas excess in age groups 15-18 and 19-24 were below the baseline with $-18.1 \%$ and $-12.0 \%$, respectively (Fig. 4). For children aged 0-14, the excess deaths decreased $-19.6 \%$ compared with the expected level. The increases in mortality were observed in people aged 25-34 and 35-60 years, with 5.9\% and 8.4\% more deaths than expected. Among the six age groups, the oldest age groups ( $>60$ years of age) were most affected by the 
medRxiv preprint doi: https://doi.org/10.1101/2022.01.07.22268886; this version posted January 7, 2022. The copyright holder for this preprint (which was not certified by peer review) is the author/funder, who has granted medRxiv a license to display the preprint in perpetuity.

It is made available under a CC-BY 4.0 International license .

177

178

COVID-19 outbreak. People in the age group of more than 60 years were exposed to death at an $11.6 \%$ higher than baseline, with men and women having roughly similar trend.

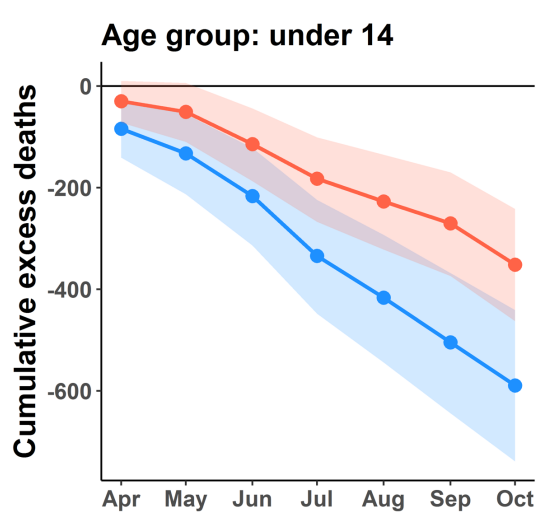

Age group: 25 to 38

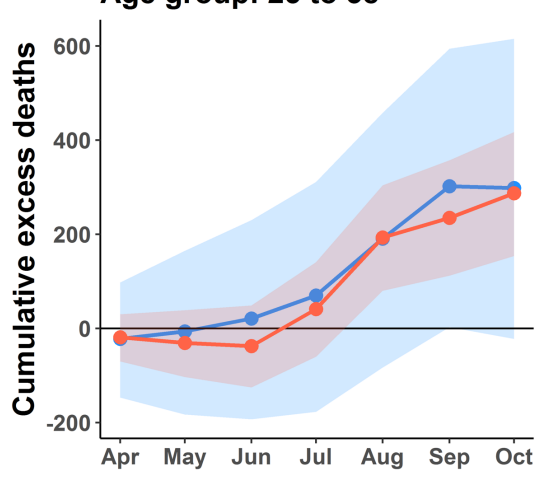

Age group: 15 to 18

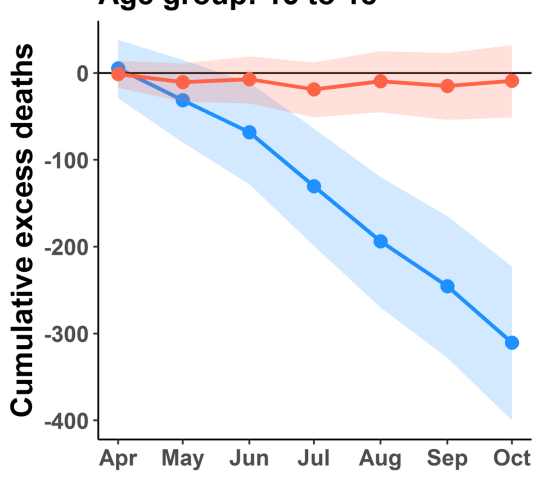

Age group: 36 to 60

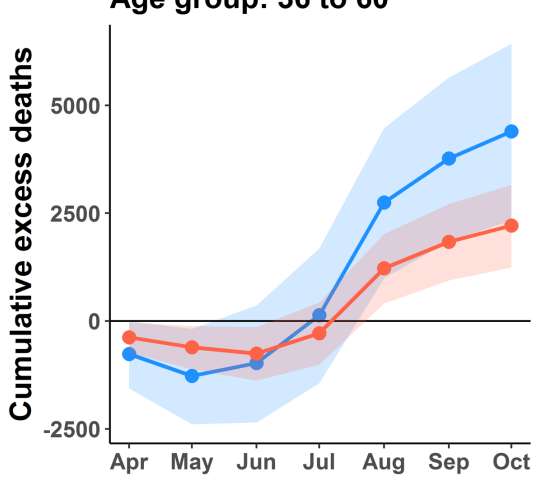

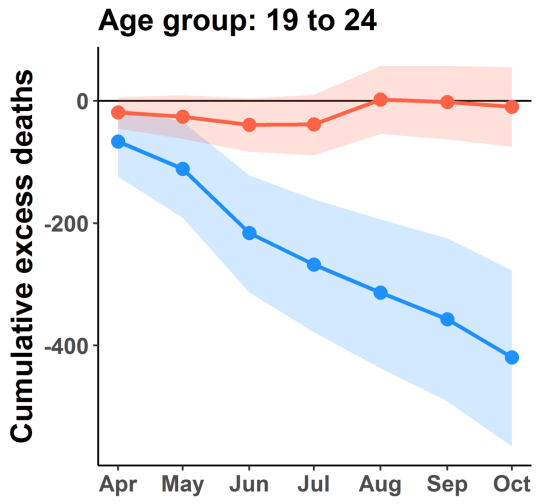

Age group: $60+$

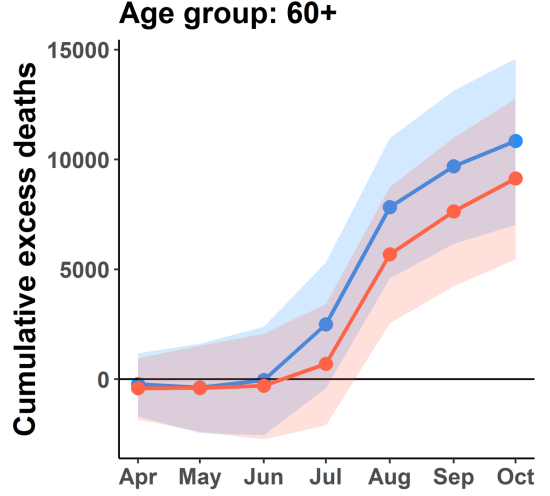

Figure 4. Cumulative excess deaths by gender and age groups. Lines illustrate the cumulative excess deaths by gender and age groups. Blue and orange lines represent men and women, respectively. Shaded areas indicate the $95 \%$ prediction intervals.

\section{Correlation of excess deaths and confirmed COVID-19 cases}

Our study demonstrated that the excess mortality across the country had increased as a consequence of the COVID-19 epidemic. The results revealed that the excess deaths substantially increased over the course of the outbreak (Fig. 5). Our model predicted that the excess mortality counts began to rise after the outbreak in April 2021. The disease spread to many provinces, with a maximum of 23,021 newly confirmed cases per day on August 13,2021[20]. We found that the trend of all-cause excess mortality agrees with the COVID-19 confirmed cases observed by the surveillance system. Quantitatively, the Pearson correlation coefficient between the cumulative 
medRxiv preprint doi: https://doi.org/10.1101/2022.01.07.22268886; this version posted January 7, 2022. The copyright holder for this preprint (which was not certified by peer review) is the author/funder, who has granted medRxiv a license to display the preprint in perpetuity.

It is made available under a CC-BY 4.0 International license.

cases and cumulative excess deaths was found to be 0.9912 (95\% CI, 0.9392-0.9987). This correlation suggests that the COVID-19 outbreaks had an impact on excess mortality.

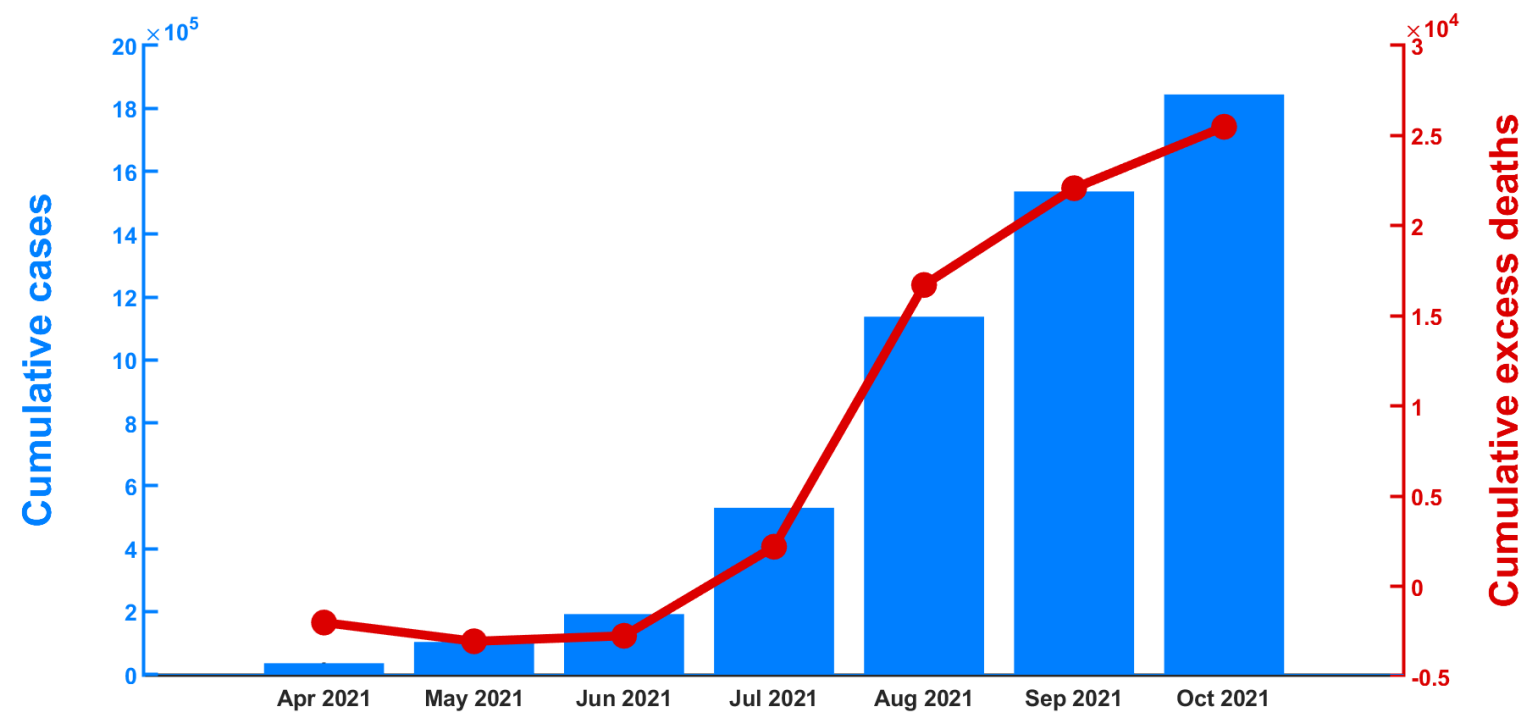

Figure 5. Excess deaths and confirmed COVID-19 cases. Bars show cumulative COVID-19 cases from April to October 2021. The red line indicates cumulative excess deaths.

\section{Discussion}

In this study, we investigated the impact of COVID-19 outbreaks on excess mortality in Thailand. We estimated all-cause excess mortality in 2021 based on historical mortality data from 2015 to 2019 . We then analyzed the age- and sex-specific mortality during 2020-2021.

Using our best model, we estimated the excess mortality in Thailand from April to October 2021. Our results highlighted that the mortality burden was increased during this period, which would be a major challenge to the healthcare system. Although, Thailand implemented social distancing and stringent lockdown measures, which comprised a national lockdown, border closure, restricting travel, and imposing nighttime curfews. The rapid rise in the number of confirmed cases resulted in the subsequent surge in the number of deaths. Our analysis suggested that death counts directly caused by the COVID-19 infection accounted for approximately $75.0 \%$ of the excess deaths. The remaining excess deaths might have been indirectly caused by COVID19. People, who are ill with other diseases, may struggle to find treatment as the impact of 
medRxiv preprint doi: https://doi.org/10.1101/2022.01.07.22268886; this version posted January 7, 2022. The copyright holder for this preprint (which was not certified by peer review) is the author/funder, who has granted medRxiv a license to display the preprint in perpetuity.

It is made available under a CC-BY 4.0 International license .

211 disruptions to the healthcare system during the COVID-19 outbreak[21-24]. There have been 212 reports of inadequate intensive care unit (ICU) beds and ventilators in Thailand[6]. A shortage of 213 ICU resources may lead to an increased risk of death for critically ill patients. Some hospitals also 214 lacked blood supplies due to a dramatic decrease in blood donations, resulting in blood shortages 215 throughout the country[25, 26].

Our analysis shows that the excess mortality is lower among young people and drastically increases with the increasing age, which is broadly consistent with the estimates in other studies[15, 27]. The excess mortality was observed mostly in the age group above 60 years of age. These demographic characteristics of mortality agree with the risk of mortality due to the COVID19 outbreak[28-30]. Furthermore, recently clinical studies[31, 32] have found that COVID-19 has a major impact on the elderly. Therefore, targeting primarily the elderly age group (via, such as, vaccination) may reduce hospitalization and mortality rates.

In contrast, the COVID-19 outbreak seemed to have less impact on the younger age group (0-24 years). All-cause mortality in the younger age group may decrease partly due to the reduction in traffic accident mortality. According to the WHO Global Status Report on Road Safety[33], Thailand ranked No.9 in the world and No.1 in Southeast Asia for road traffic deaths, with an estimated road traffic death rate of 33 deaths per 100,000 people in 2018[34]. Moreover, traffic accidents were the third leading cause of death in Thailand in 2020[35]. However, the data in 2021 suggests that traffic accident fatalities have decreased substantially during the course of the COVID-19 outbreak (Fig. S6 in the supplementary information). The mobility data reported by Apple also suggested that driving and walking mobility tend to decrease during this period. The number of deaths caused by traffic accidents has decreased markedly in the male population (Fig. S7 in the supplementary information). Specifically, the average number of deaths caused by traffic accidents decreased approximately $20 \%$ compared to the previous year. Therefore, our findings might reflect reduced all-cause mortality in the younger age group of men, partly due to the reduction in traffic accident mortality as a result of lockdown measures.

Our results showed higher excess deaths in males than in females. Although the trend of sex-specific deaths in 2021 compared to the previous four years showed a similar trend for men and women, the magnitude of excess mortality is higher for men, specifically in three age groups

$240(25-34,35-60$, and over 60 years of age). There was a noticeable sex difference in excess mortality 
medRxiv preprint doi: https://doi.org/10.1101/2022.01.07.22268886; this version posted January 7, 2022. The copyright holder for this preprint (which was not certified by peer review) is the author/funder, who has granted medRxiv a license to display the preprint in perpetuity.

It is made available under a CC-BY 4.0 International license .

241

242

243

244

245

246

247

248

249

250

251

252

253

254

255

256

257

258

259

260

261

262

263

264

265

266

267

in age groups older than 25 years. These demographics of excess mortality were also found in other countries such as England and Wales[15], Sweden[27], Italy[36, 37], and Brazil[38]. These studies revealed that the majority of excess deaths were attributable to COVID-19. Moreover, other studies suggest that the risk of COVID-related death in males may be related to susceptibility to severe SARS-CoV-2 infections and male hormones[39-41]. Therefore, gender could be a risk factor for COVID-related mortality.

Our study, however, has some limitations. In this work, we did not consider other influential factors of death, such as influenza, pneumonia, and respiratory syncytial virus infection, due to the lack of data. The empirical findings from N. Suntronwong et al.[42] revealed that the advent of COVID-19 may change human behavior, such as wearing face masks and social distancing, resulting in a decreased transmission of influenza in Thailand. In addition, we did not consider other factors such as effects of heatwaves and ambient air pollution that may correlate with mortality $[43,44]$ due to the limitation of data. Future work may investigate these factors when the data becomes available.

In summary, our findings showed that the COVID-19 outbreak in Thailand had a huge impact on mortality. During the outbreak in 2021, there was a significant rise in excess fatalities, especially in the older age groups. The increase in mortality was found to be higher in men than in women. It is worth stressing that up-to-date and reliable mortality data are important to assess the impact of the COVID-19 pandemic. Our modeling results could potentially provide insights into the COVID-19 outbreaks and provide a guide for outbreak control and intervention.

\section{Abbreviations}

COVID-19: Coronavirus disease 2019; SARS-CoV-2: Severe acute respiratory syndrome coronavirus - 2; GLMMs: generalized linear mixed models; CI: confidence interval; AIC: Akaike information criterion

\section{Acknowledgments}


medRxiv preprint doi: https://doi.org/10.1101/2022.01.07.22268886; this version posted January 7, 2022. The copyright holder for this preprint (which was not certified by peer review) is the author/funder, who has granted medRxiv a license to display the preprint in perpetuity.

It is made available under a CC-BY 4.0 International license .

268 This work was supported by Faculty of Science, Naresuan University. C.M. was supported by the

269 National Research Council of Thailand and the Thailand Center of Excellence in Physics.

270

271 Authors' Contributions

272 CW: participated in its design, performed the analysis, wrote the first draft. TL: participated in

273 data extraction and interpretation. CM: participated in its design, analyzed the results, and wrote

274 the manuscript. SC: conceptualized, participated in its design, analyzed the results, and wrote the

275 manuscript. All authors read and approved the final manuscript.

276

277 Funding

278 Not applicable

279

280

Availability of Data and Materials

281 The data supporting the findings can be found in the main paper.

282

283

\section{Declarations}

284 Ethics approval and consent to participate

285 The need for approval was waived as this study used published data.

286

287 Consent for publication

288 Not applicable

289

290

Competing interests 
medRxiv preprint doi: https://doi.org/10.1101/2022.01.07.22268886; this version posted January 7, 2022. The copyright holder for this preprint (which was not certified by peer review) is the author/funder, who has granted medRxiv a license to display the preprint in perpetuity.

It is made available under a CC-BY 4.0 International license .

The authors declare that they have no competing interests.

\section{References}

294

295

296

297

298

299

300

301

302

303

304

305

306

307

308

309

310

311

312

313

314

315

316

317

318

319

320

321

322

323

324

325

326

327

328

329

330

331

332

1. Chookajorn T, Kochakarn T, Wilasang C, Kotanan N, Modchang C: Southeast Asia is an emerging hotspot for COVID-19. Nature Medicine 2021, 27(9):1495-1496.

2. Thailand: Coronavirus Pandemic Country Profile [https://ourworldindata.org/coronavirus/country/thailand]

3. Boon-Itt S, Rompho N, Jiarnkamolchurn S, Skunkan Y: Interaction between age and health conditions in the intention to be vaccinated against COVID-19 in Thailand. Human Vaccines \& Immunotherapeutics 2021:1-7.

4. Covid beds running out [https://www.bangkokpost.com/thailand/general/2136647/covid-beds-running-out]

5. Thailand faces hospital bed shortage amid 3rd COVID wave [https://asia.nikkei.com/Spotlight/Coronavirus/Thailand-faces-hospital-bed-shortageamid-3rd-COVID-wave]

6. Marshall AI, Archer R, Witthayapipopsakul W, Sirison K, Chotchoungchatchai S, Sriakkpokin P, Srisookwatana O, Teerawattananon Y, Tangcharoensathien V: Developing a Thai national critical care allocation guideline during the COVID-19 pandemic: a rapid review and stakeholder consultation. Health Research Policy and Systems 2021, 19(1):1-15.

7. Aumpan N, Vilaichone R-k, Ratana-Amornpin S, Teerakapibal S, Toochinda P, Witoonchart G, Nitikraipot S: Antiviral treatment could not provide clinical benefit in management of mild COVID-19: A Retrospective Experience from Field hospital. Journal of Infection and Public Health 2021, 14(9):1206-1211.

8. Coronavirus (COVID-19) Deaths [https://ourworldindata.org/covid-deaths]

9. Murtas R, Russo AG: Effects of pollution, low temperature and influenza syndrome on the excess mortality risk in winter 2016-2017. BMC Public Health 2019, 19(1):1-9.

10. Gasparrini A, Guo Y, Sera F, Vicedo-Cabrera AM, Huber V, Tong S, Coelho MdSZS, Saldiva PHN, Lavigne E, Correa PM: Projections of temperature-related excess mortality under climate change scenarios. The Lancet Planetary Health 2017, 1(9):e360-e367.

11. Cooper BS, Kotirum S, Kulpeng W, Praditsitthikorn N, Chittaganpitch M, Limmathurotsakul D, Day NP, Coker R, Teerawattananon Y, Meeyai A: Mortality attributable to seasonal influenza $A$ and $B$ infections in Thailand, 2005-2009: a longitudinal study. American journal of epidemiology 2015, 181(11):898-907.

12. Rosano A, Bella A, Gesualdo F, Acampora A, Pezzotti P, Marchetti S, Ricciardi W, Rizzo $\mathrm{C}$ : Investigating the impact of influenza on excess mortality in all ages in Italy during recent seasons (2013/14-2016/17 seasons). International Journal of Infectious Diseases 2019, 88:127-134.

13. Freitas ARR, Cavalcanti L, Von Zuben AP, Donalisio MR: Excess mortality related to chikungunya epidemics in the context of co-circulation of other arboviruses in Brazil. PLoS currents 2017, 9. 
medRxiv preprint doi: https://doi.org/10.1101/2022.01.07.22268886; this version posted January 7, 2022. The copyright holder for this preprint (which was not certified by peer review) is the author/funder, who has granted medRxiv a license to display the preprint in perpetuity.

It is made available under a CC-BY 4.0 International license .

14. Darby S, Rizza C, Doll R, Spooner R, Stratton I, Thakrar B: Incidence of AIDS and excess of mortality associated with HIV in haemophiliacs in the United Kingdom: report on behalf of the directors of haemophilia centres in the United Kingdom. British Medical Journal 1989, 298(6680):1064-1068.

15. Aburto JM, Kashyap R, Schöley J, Angus C, Ermisch J, Mills MC, Dowd JB: Estimating the burden of the COVID-19 pandemic on mortality, life expectancy and lifespan inequality in England and Wales: a population-level analysis. J Epidemiol Community Health 2021.

16. Official Statistics $\quad$ Registration $\quad$ Systems [https://stat.bora.dopa.go.th/stat/statnew/statMenu/newStat/home.php]

17. Johns Hopkins University J: Dashboard by the Center for Systems Science and Engineering (CSSE) at Johns Hopkins University (JHU). Baltimore, Maryland: John Hopkins University Coronvirus Resource Centre 2020.

18. Population Pyramids of the World from 1950 to 2100 [https://www.populationpyramid.net/]

19. Coronavirus disease 2019 (COVID-19) WHO Thailand Situation Report 197 - 19 August 2021 [https://reliefweb.int/report/thailand/coronavirus-disease-2019-covid-19who-thailand-situation-report-197-19-august-2021]

20. Coronavirus disease 2019 (COVID-19) WHO Thailand Situation Report 205 - 14 October 2021 [https://reliefweb.int/report/thailand/coronavirus-disease-2019-covid-19who-thailand-situation-report-205-14-october-2021]

21. Kulkarni GS, Urbach DR, Austin PC, Fleshner NE, Laupacis A: Longer wait times increase overall mortality in patients with bladder cancer. The Journal of urology 2009, 182(4):1318-1324.

22. Plunkett PK, Byrne DG, Breslin T, Bennett K, Silke B: Increasing wait times predict increasing mortality for emergency medical admissions. European Journal of Emergency Medicine 2011, 18(4):192-196.

23. Hanna TP, Evans GA, Booth CM: Cancer, COVID-19 and the precautionary principle: prioritizing treatment during a global pandemic. Nature reviews Clinical oncology 2020, 17(5):268-270.

24. Rosenbaum L: The untold toll—the pandemic's effects on patients without Covid-19. 2020, 382(24):2368-2371.

25. Impact of COVID-19 Pandemic on Blood Donation [https://english.redcross.or.th/news/blood-transfusion-services/5543/]

26. Red Cross in urgent of need blood [https://www.bangkokpost.com/thailand/general/2103991/red-cross-in-urgent-need-ofblood]

27. Modig K, Ahlbom A, Ebeling M: Excess mortality from COVID-19: weekly excess death rates by age and sex for Sweden and its most affected region. European journal of public health 2021, 31(1):17-22.

28. Dessie ZG, Zewotir T: Mortality-related risk factors of COVID-19: a systematic review and meta-analysis of 42 studies and 423,117 patients. BMC Infectious Diseases 2021, 21(1):1-28.

29. Amore S, Puppo E, Melara J, Terracciano E, Gentili S, Liotta G: Impact of COVID-19 on older adults and role of long-term care facilities during early stages of epidemic in Italy. Scientific reports 2021, 11(1):1-13. 
medRxiv preprint doi: https://doi.org/10.1101/2022.01.07.22268886; this version posted January 7, 2022. The copyright holder for this preprint (which was not certified by peer review) is the author/funder, who has granted medRxiv a license to display the preprint in perpetuity. It is made available under a CC-BY 4.0 International license .

30. O'Driscoll M, Dos Santos GR, Wang L, Cummings DA, Azman AS, Paireau J, Fontanet A, Cauchemez S, Salje H: Age-specific mortality and immunity patterns of SARSCoV-2. Nature 2021, 590(7844):140-145.

31. Kang S-J, Jung SI: Age-related morbidity and mortality among patients with COVID19. Infection \& chemotherapy 2020, 52(2):154.

32. Hägg S, Jylhävä J, Wang Y, Xu H, Metzner C, Annetorp M, Garcia-Ptacek S, Khedri M, Boström A-M, Kadir A: Age, frailty, and comorbidity as prognostic factors for shortterm outcomes in patients with coronavirus disease 2019 in geriatric care. Journal of the American Medical Directors Association 2020, 21(11):1555-1559. e1552.

33. World Health Organization W: Global status report on road safety 2018: summary. In.: World Health Organization; 2018.

34. Chantith C, Permpoonwiwat CK, Hamaide B: Measure of productivity loss due to road traffic accidents in Thailand. IATSS research 2021, 45(1):131-136.

35. Tanaboriboon Y, Satiennam T: Traffic accidents in Thailand. IATSS research 2005, 29(1):88-100.

36. Michelozzi P, de'Donato F, Scortichini M, Pezzotti P, Stafoggia M, De Sario M, Costa G, Noccioli F, Riccardo F, Bella A: Temporal dynamics in total excess mortality and COVID-19 deaths in Italian cities. BMC Public Health 2020, 20(1):1-8.

37. Gallo E, Prosepe I, Lorenzoni G, Acar AŞ, Lanera C, Berchialla P, Azzolina D, Gregori D: Excess of all-cause mortality is only partially explained by COVID-19 in Veneto (Italy) during spring outbreak. BMC Public Health 2021, 21(1):1-6.

38. Jardim BC, Santos CVBd: Excess mortality in Brazil in times of Covid-19. Ciência \& Saúde Coletiva 2020, 25:3345-3354.

39. Brandi ML, Giustina A: Sexual dimorphism of coronavirus 19 morbidity and lethality. Trends in Endocrinology \& Metabolism 2020.

40. Aksoyalp ZŞ, Nemutlu-Samur D: Sex-related susceptibility in coronavirus disease 2019 (COVID-19): Proposed mechanisms. European Journal of Pharmacology 2021:174548.

41. Spagnolo PA, Manson JE, Joffe H: Sex and gender differences in health: what the COVID-19 pandemic can teach us. In.: American College of Physicians; 2020.

42. Suntronwong N, Thongpan I, Chuchaona W, Budi Lestari F, Vichaiwattana P, Yorsaeng R, Pasittungkul S, Kitphati R, Vongpunsawad S, Poovorawan Y: Impact of COVID-19 public health interventions on influenza incidence in Thailand. Pathogens and Global Health 2020, 114(5):225-227.

43. Huang C, Cheng J, Phung D, Tawatsupa B, Hu W, Xu Z: Mortality burden attributable to heatwaves in Thailand: A systematic assessment incorporating evidence-based lag structure. Environment international 2018, 121:41-50.

44. Pinichka C, Makka N, Sukkumnoed D, Chariyalertsak S, Inchai P, Bundhamcharoen K: Burden of disease attributed to ambient air pollution in Thailand: A GIS-based approach. PloS one 2017, 12(12):e0189909. 
423

424

425

426

427

428

429

430

431

432

433

434

435

436

437

\section{Additional files}

\section{Deaths due to COVID-19}

The number of daily COVID-19 deaths in Thailand was retrieved from the Center for Systems Science and Engineering (CSSE) at Johns Hopkins University ${ }^{1}$.

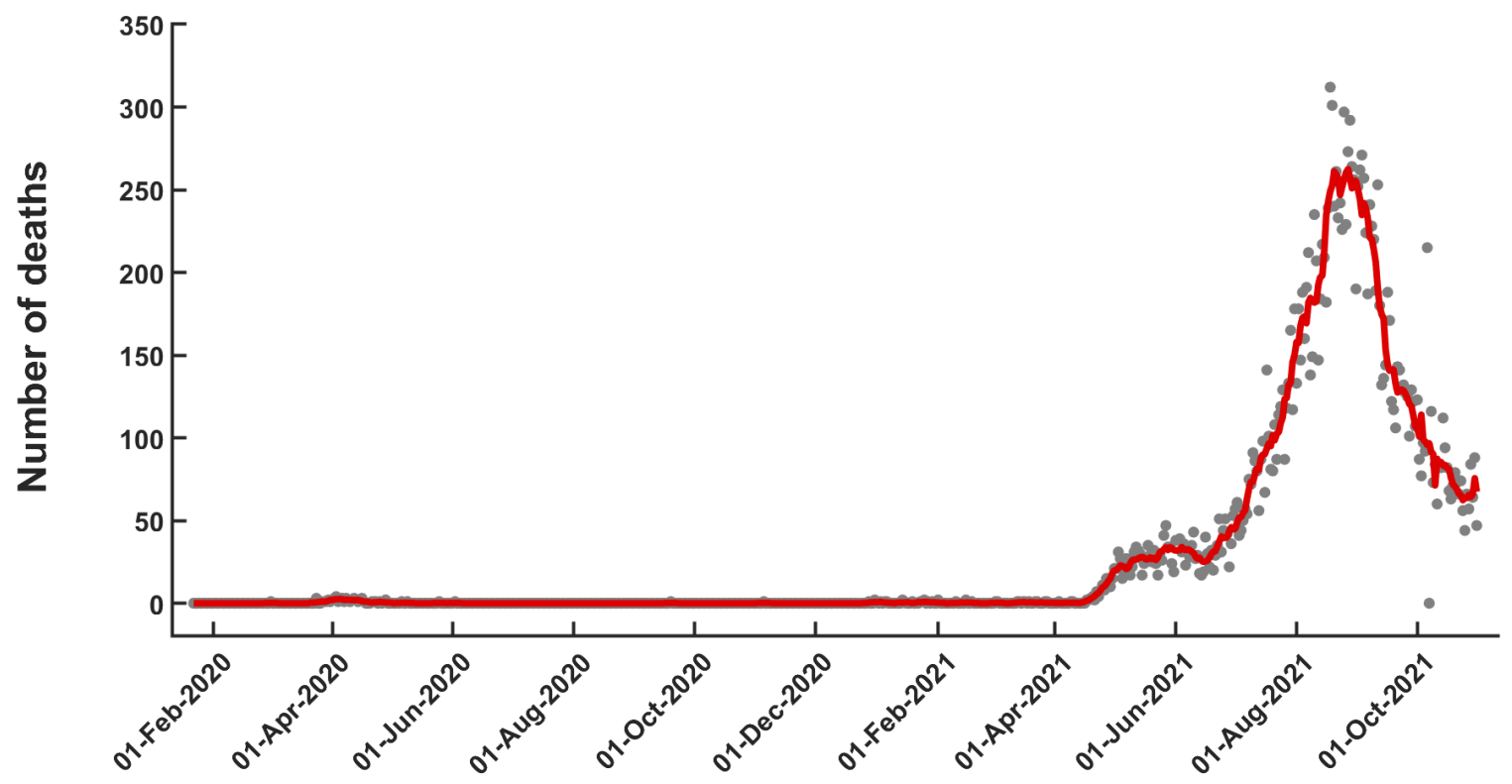

Figure S1. Daily confirmed COVID-19 deaths. The green line illustrates the number of COVID19 deaths starting from January 22, 2020, to October 31, 2021 in Thailand.

\section{Estimation of the baseline mortality}

We used mortality data from January 2015 to December 2019 by age and sex for fitting the models. The three models have different structures as follows.

\section{Model B:}

$$
Y_{t} \sim \beta_{1} * \text { time }_{t} * \operatorname{sex}_{t} * \operatorname{agegroup}_{t}
$$$$
+\beta_{2} * \sin \left(\frac{2 \pi *(\text { month } / 30)}{365.25}\right) * \operatorname{sex}_{t} * \operatorname{agegroup}_{t}
$$$$
+\beta_{3} * \cos \left(\frac{2 \pi *(\text { month } / 30)}{365.25}\right) * \text { sex }_{t} * \text { agegroup }_{t}
$$ 
medRxiv preprint doi: https://doi.org/10.1101/2022.01.07.22268886; this version posted January 7, 2022. The copyright holder for this preprint (which was not certified by peer review) is the author/funder, who has granted medRxiv a license to display the preprint in perpetuity. It is made available under a CC-BY 4.0 International license.

$$
\begin{aligned}
& +\beta_{4} * \sin \left(\frac{2 \pi *(\text { month } / 30)}{365.25 / 2}\right) * \text { sex }_{t} * \text { agegroup }_{t} \\
& +\beta_{5} * \cos \left(\frac{2 \pi *(\text { month } / 30)}{365.25 / 2}\right) * \text { sex }_{t} * \text { agegroup }_{t}
\end{aligned}
$$$$
+\beta_{6} * \text { off } \operatorname{set}\left(\log \left(\text { exposure }_{t}\right)\right)
$$

The observed and baseline mortality stratified by age group in 2015-2021 for men and women, are shown in Fig S2-S3, respectively.
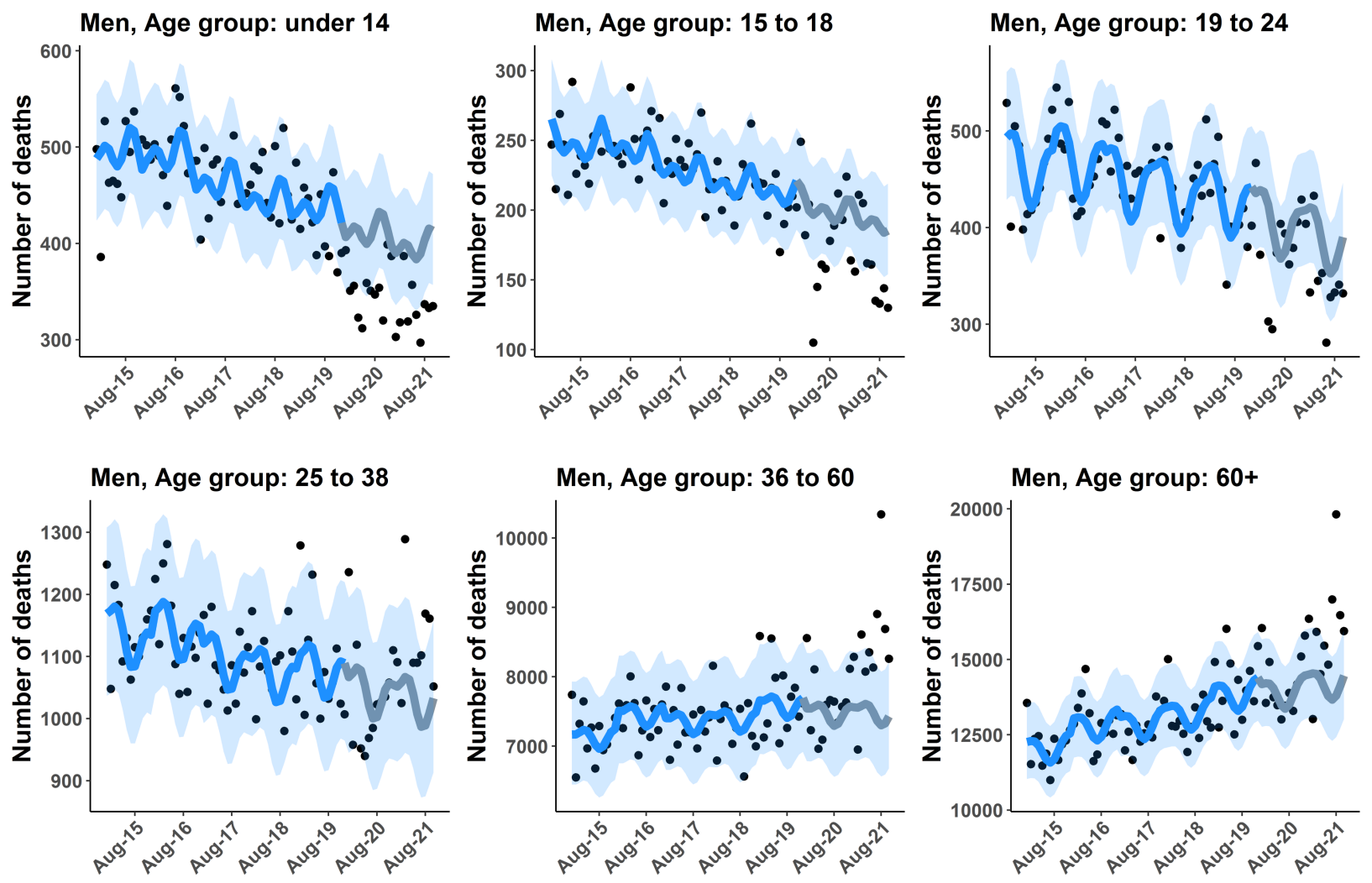

Figure S2. Men baseline mortality from Model B. Lines illustrate the baseline mortality by six age groups $(0-14,15-18,19-24,25-34,35-60$ and over 60 years of age). Grey lines show the predicted baseline starting from January 2020 to October 2021. Points shows the observed mortality data. Shaded areas indicate $95 \%$ CI. 
medRxiv preprint doi: https://doi.org/10.1101/2022.01.07.22268886; this version posted January 7, 2022. The copyright holder for this preprint (which was not certified by peer review) is the author/funder, who has granted medRxiv a license to display the preprint in perpetuity.
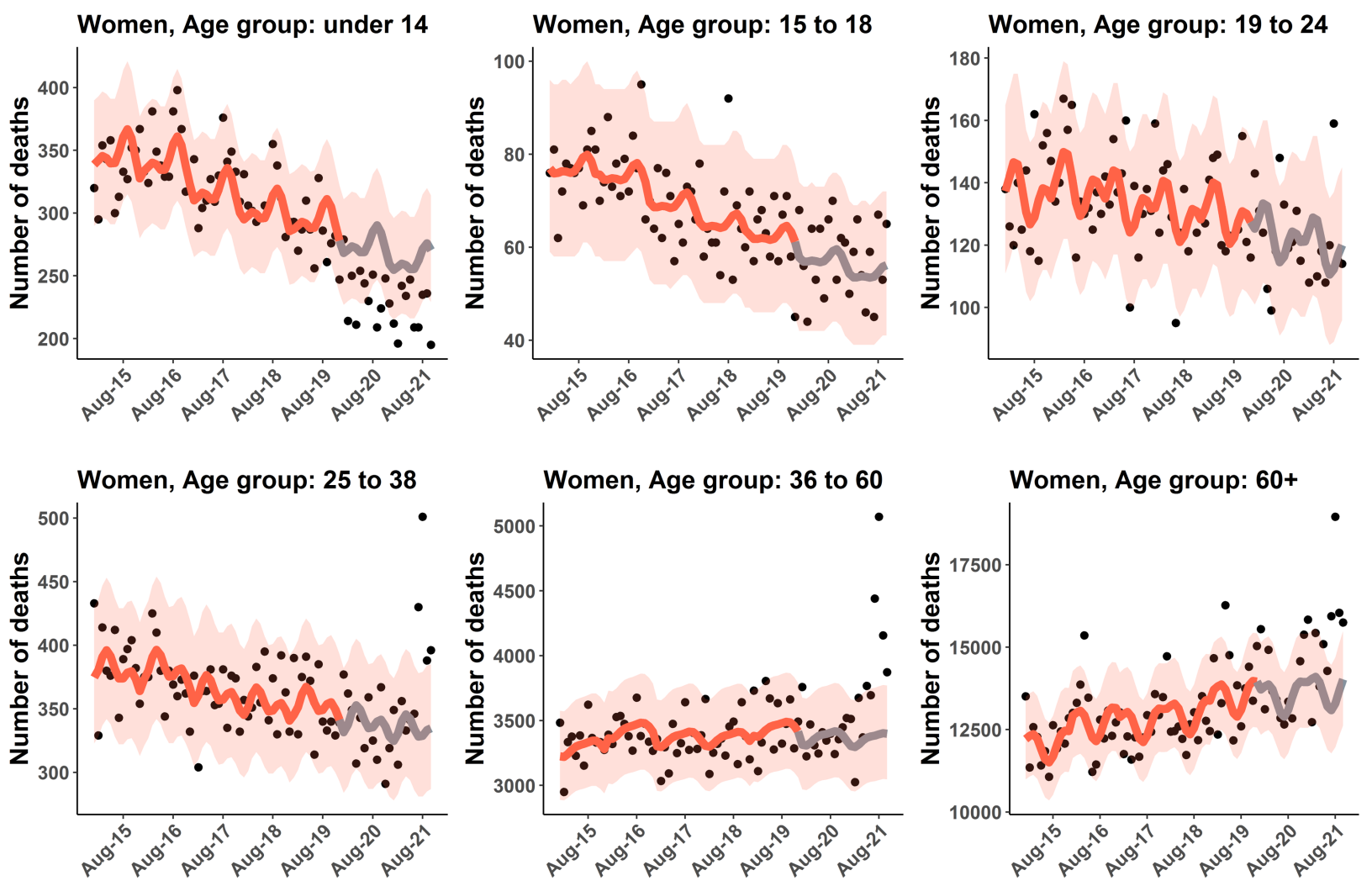

453

Figure S3. Women baseline mortality from Model B. Lines illustrate the baseline mortality by 454 six age groups $(0-14,15-18,19-24,25-34,35-60$ and over 60 years of age). Grey lines show the predicted baseline starting from January 2020 to October 2021. Points shows the observed mortality data. Shaded areas indicate $95 \%$ CI.

\section{Model C:}

$$
Y_{t} \sim \beta_{1} * \text { time }_{t} * \operatorname{sex}_{t} * \operatorname{agegroup}_{t}
$$$$
+\beta_{2} * \sin \left(\frac{2 \pi *(\text { month } / 30)}{365.25}\right) * \text { sex }_{t} * \text { agegroup }_{t}
$$

$$
+\beta_{3} * \cos \left(\frac{2 \pi *(\text { month } / 30)}{365.25}\right) * \operatorname{sex}_{t} * \operatorname{agegroup}_{t}
$$

$$
+\beta_{4} * \text { offset }\left(\log \left(\operatorname{exposure}_{t}\right)\right)
$$


medRxiv preprint doi: https://doi.org/10.1101/2022.01.07.22268886; this version posted January 7, 2022. The copyright holder for this preprint (which was not certified by peer review) is the author/funder, who has granted medRxiv a license to display the preprint in perpetuity.

464 The observed and baseline mortality stratified by age group in 2015-2021 for men and women, are 465 shown in Fig S4-S5, respectively.
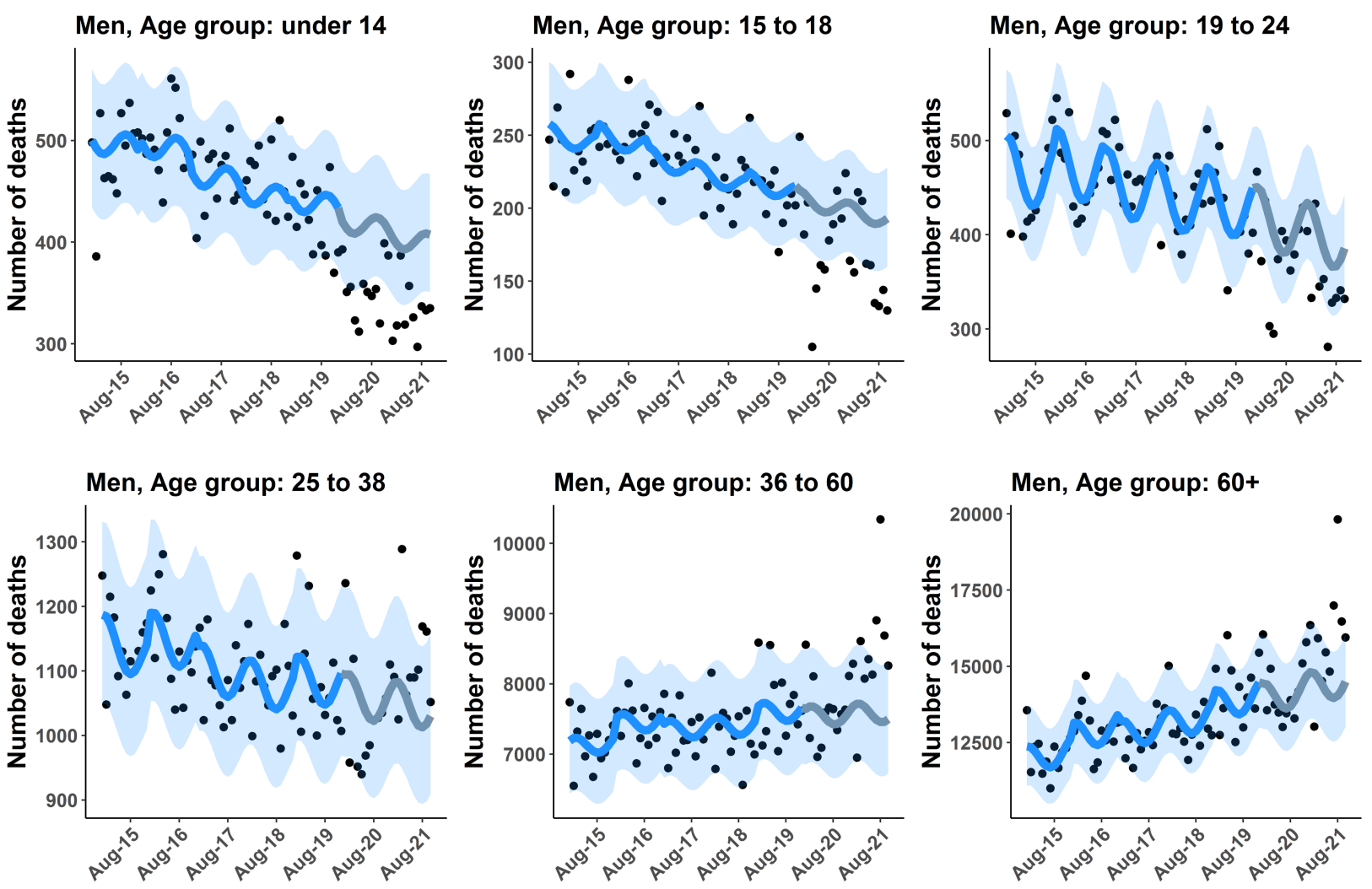

Figure S4. Men baseline mortality from Model C. Lines illustrate the baseline mortality by six age groups $(0-14,15-18,19-24,25-34,35-60$ and over 60 years of age). Grey lines show the predicted baseline starting from January 2020 to October 2021. Points shows the observed mortality data. Shaded areas indicate $95 \%$ CI. 
medRxiv preprint doi: https://doi.org/10.1101/2022.01.07.22268886; this version posted January 7, 2022. The copyright holder for this preprint (which was not certified by peer review) is the author/funder, who has granted medRxiv a license to display the preprint in perpetuity.

It is made available under a CC-BY 4.0 International license.

472

473

474

475

476

477

478

479

480

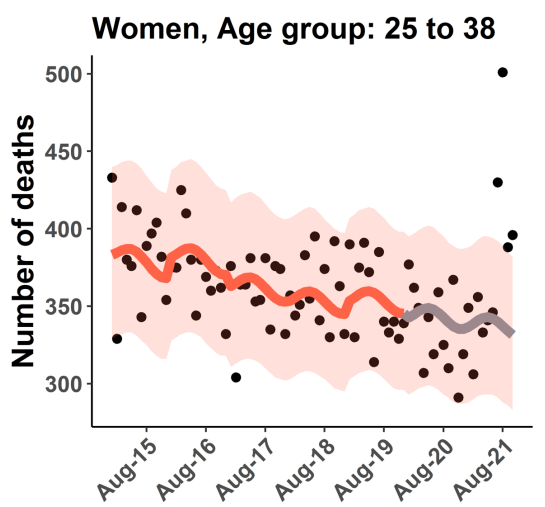
quality of each model.

Table S1. Model comparison.

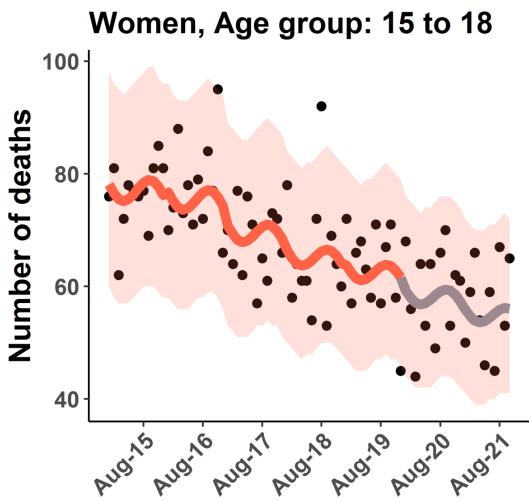

Women, Age group: 36 to 60

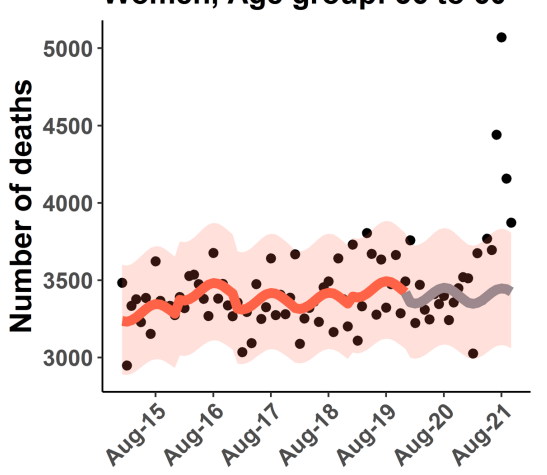

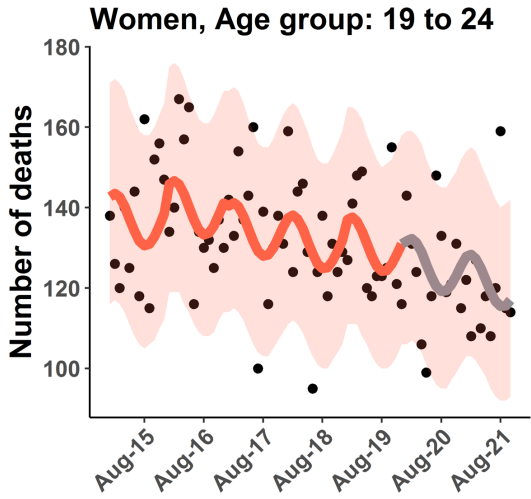

Women, Age group: 60+

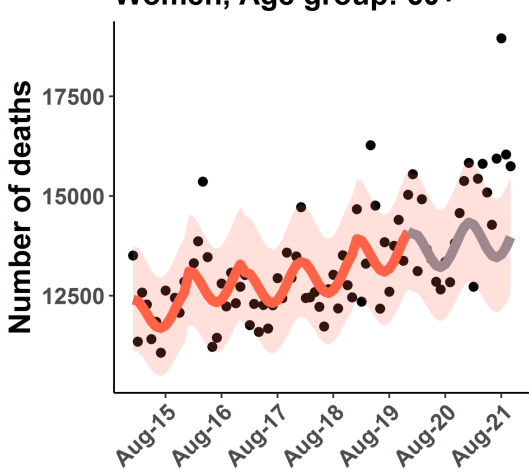

Figure S5. Women baseline mortality from Model C. Lines illustrate the baseline mortality by six age groups (0-14, 15-18, 19-24, 25-34, 35-60 and over 60 years of age). Grey lines show the predicted baseline starting from January 2020 to October 2021. Points shows the observed mortality data. Shaded areas indicate 95\% CI.

A summary of four different models is shown in Table S1. We used AIC to estimate the

\begin{tabular}{|l|c|c|c|}
\hline \multicolumn{1}{|c|}{ Model } & AIC & Number parameters & Number coefficients \\
\hline Model A & 8095.2 & 8 & 72 \\
\hline Model B & 8123.5 & 8 & 72 \\
\hline Model C & 8108.1 & 6 & 48 \\
\hline
\end{tabular}


medRxiv preprint doi: https://doi.org/10.1101/2022.01.07.22268886; this version posted January 7, 2022. The copyright holder for this preprint (which was not certified by peer review) is the author/funder, who has granted medRxiv a license to display the preprint in perpetuity.

It is made available under a CC-BY 4.0 International license.

\section{Traffic accident mortality data}

483

Figure S6 shows the traffic accident mortality deaths from January 2017 to October 2021

484 and the mobility trends in Thailand. Data on traffic accident-related deaths was acquired from the

485 Road Accidents Data Center for Road Safety Culture of Thailand (Thai RSC) ${ }^{2}$. The accident

486 mortality data were also stratified by age group and gender (Fig S7). The number of people dying

487 from traffic accidents was categorized into six age groups (0-14, 15-18, 19-24, 25-34, 35-60, and

488 over 60 years of age). The data suggested that after the Thai government implemented social

489 distancing and stringent lockdown measures, the number of traffic accident deaths decreased by

490 approximately $20 \%$ compared with the average traffic accident deaths of the previous year.

491 Moreover, we used the mobility in Thailand reported by Apple ${ }^{3}$ as a representative of the mobility

492 in Thailand during lockdown. Driving and walking mobility tend to decrease compared with 493 baseline. 
medRxiv preprint doi: https://doi.org/10.1101/2022.01.07.22268886; this version posted January 7, 2022. The copyright holder for this preprint (which was not certified by peer review) is the author/funder, who has granted medRxiv a license to display the preprint in perpetuity.

It is made available under a CC-BY 4.0 International license.

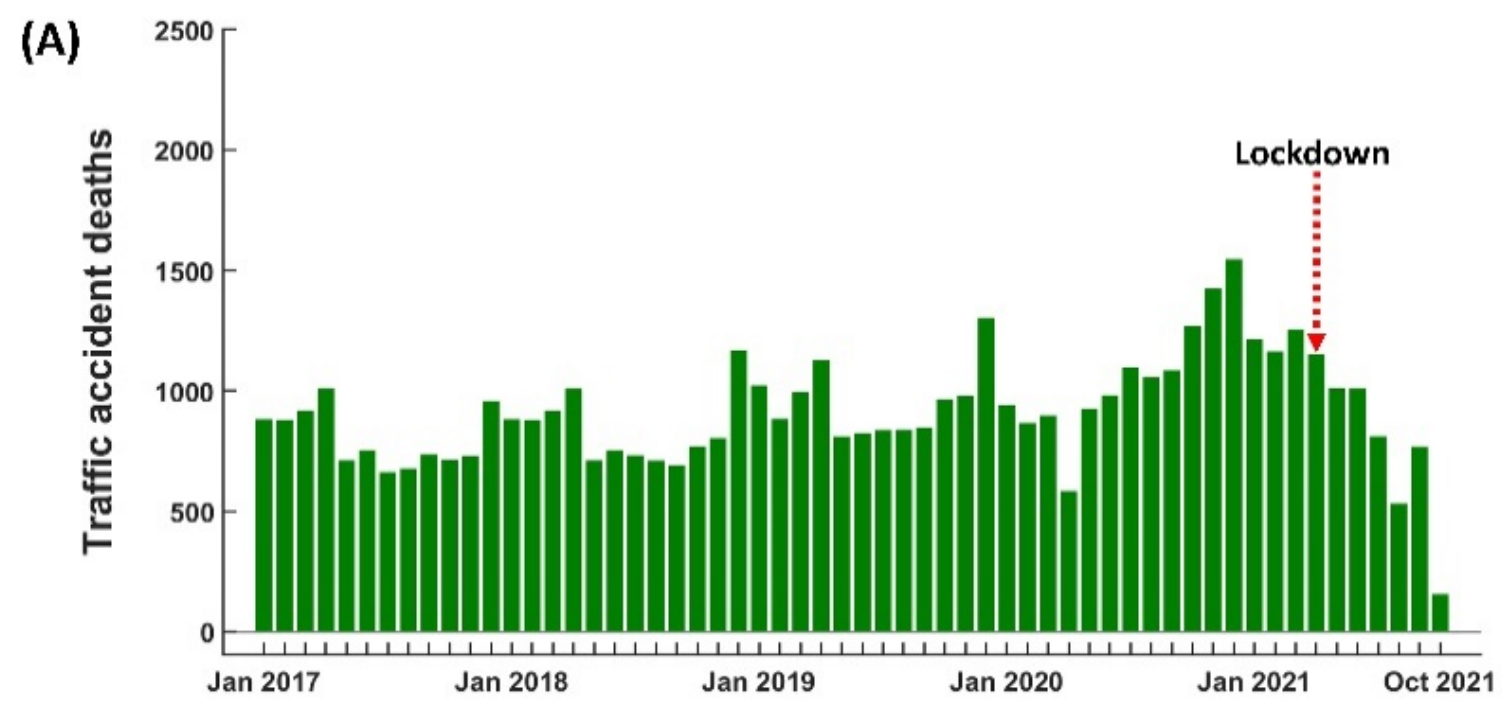

(B)

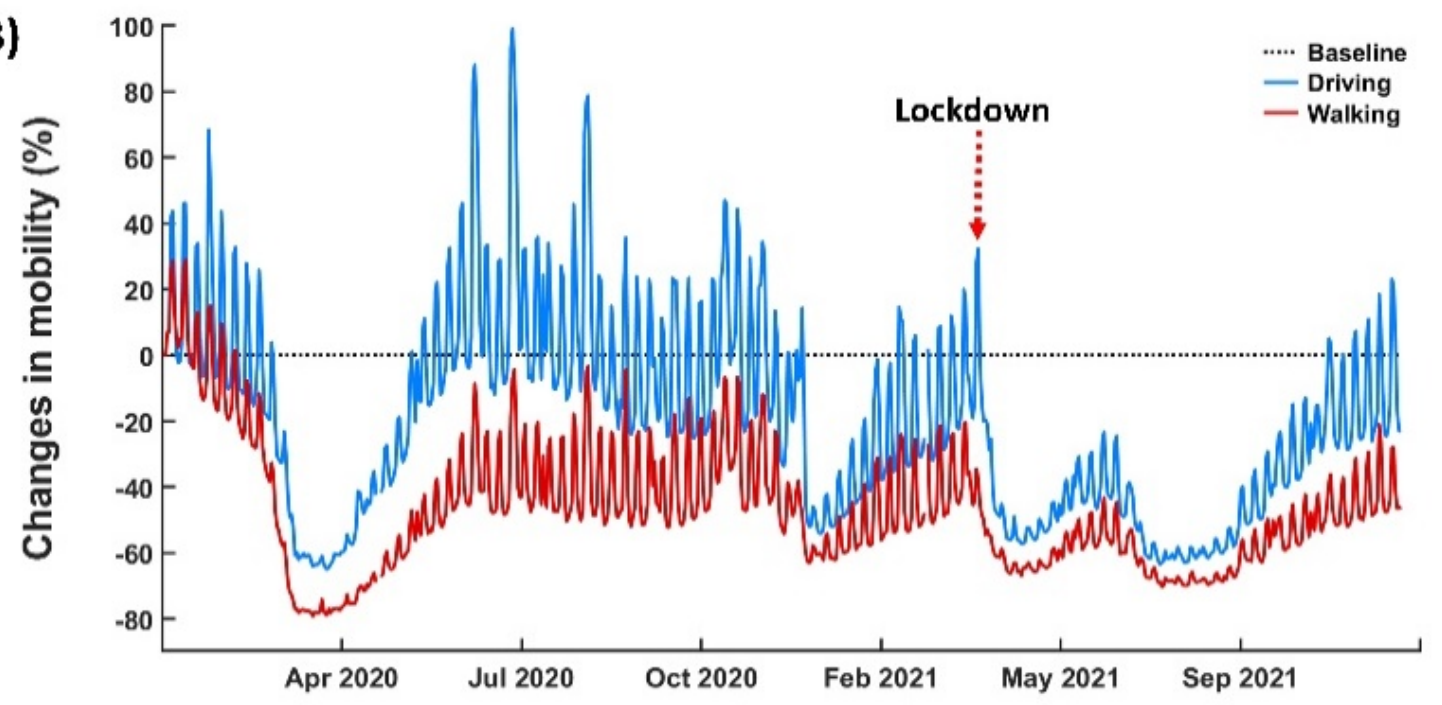

Figure S6. Traffic accident mortality data and mobility trends data. (A) Traffic accident mortality data from January 2017 to October 2021. (B) The mobility in Thailand reported by Apple. 
medRxiv preprint doi: https://doi.org/10.1101/2022.01.07.22268886; this version posted January 7, 2022. The copyright holder for this preprint (which was not certified by peer review) is the author/funder, who has granted medRxiv a license to display the preprint in perpetuity.

It is made available under a CC-BY 4.0 International license.

500
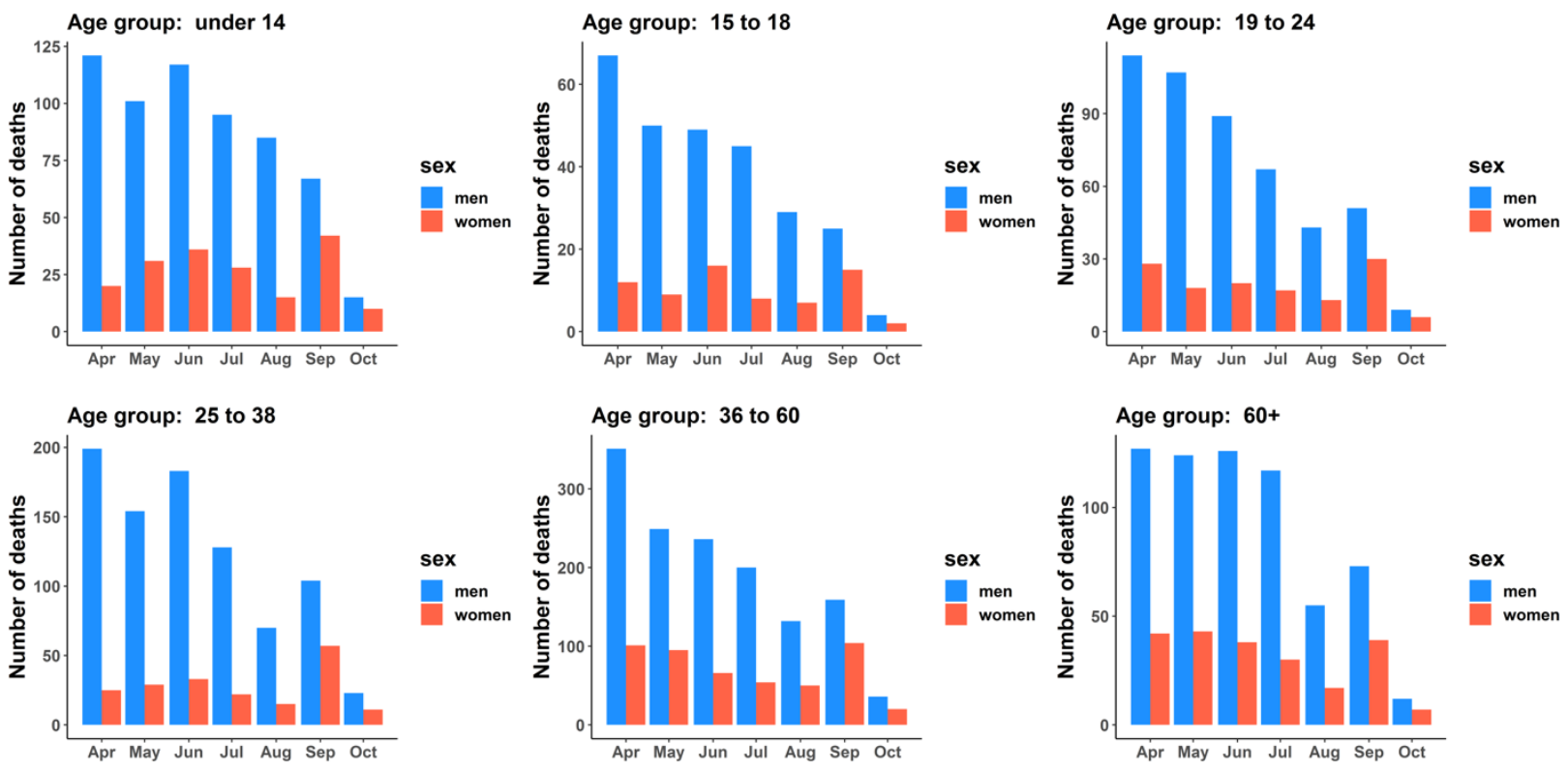

Figure S7. Traffic accident deaths by gender and age groups. Bars show the monthly traffic accident deaths by gender and age groups starting from April to October 2021. 
medRxiv preprint doi: https://doi.org/10.1101/2022.01.07.22268886; this version posted January 7, 2022. The copyright holder for this preprint (which was not certified by peer review) is the author/funder, who has granted medRxiv a license to display the preprint in perpetuity.

It is made available under a CC-BY 4.0 International license.

\section{References}

5111 Johns Hopkins University, J. Dashboard by the Center for Systems Science and

512 Engineering (CSSE) at Johns Hopkins University (JHU). Baltimore, Maryland: John $513 \quad$ Hopkins University Coronvirus Resource Centre (2020).

5142 Road Accidents Data Center for Road Safety Culture of Thailand, T. Traffic accident515 related mortality data, < https://www.thairsc.com/> (2021).

5163 Apple. COVID-19-Mobility Trends Reports Apple, $<$ https://covid19.apple.com/mobility> $517 \quad$ (2021).

518

519

520

521 